\title{
The Effects of Corporate Social Responsibility on Job Performance: Moderating Effects of Authentic Leadership and Meaningfulness of Work
}

\author{
Hoe-Chang Yang ${ }^{1}$, Young-Ei Kim ${ }^{2}$ \\ Received: May 30, 2018 Revised: July 20, 2018 Accepted: July 30, 2018
}

\begin{abstract}
The study aims to investigate methods for companies to contribute to not only social and national developments, but also on the promotion of individuals and companies by re-examining the various phenomena that define companies. The study examines the relationship between subordinate factors of social responsibility activities and job performances as well as the role of CEOs in showing authentic leadership and meaningfulness of work. A total of 312 valid questionnaires were obtained, and hypotheses were tested using regression analysis, hierarchical regression analysis, and 3-way interactions. The results suggest that corporate social responsibility activities not only enhanced the performance of the members, but also confirmed the importance of the authentic leadership of the CEO. Additionally, the role of the members in the company also showed to play a very significant role in a company's developments. The results also show that the CEO and members need to make efforts to increase ethics as well as gain more competitiveness and improve their reputation by promoting their sense of calling and feeling of compassion in the workplace. In other words, the members of the high-ranking book and the members of the relatively low position will have different degrees of information transfer and evaluation of the company policy may be different.
\end{abstract}

Keywords: Corporate Social Responsibility, Job Performance, Authentic Leadership, Meaningfulness of Work, 3-way Interaction, Korea

JEL Classification Code: J17, L10, M10, M12.

\section{Introduction}

The revitalization of the Internet and the spread of mobile devices are causing rapid changes in many areas of our society. It is progressing at a rapid rate that we cannot predict how they will change. These changes will not only lead to structural changes in the business, but also to people's communication patterns, procedures, and participation patterns, as well as the flow and sharing of information for the future (Kim \& Kim, 2012). This phenomenon of social change has made it desirable for companies to build a positive image through active social responsibility activities, but it also increases the risk of exposure to mass confusion. A positive example is Otto Gigi's Chairman Ham Tae-ho and LG Group Chairman Koo

1 First Author, Assistant Professor, Dept. of Distribution Management, Jangan University, Hwaseong, Korea.

Email: pricezzang@jangan.ac.kr

2 Corresponding Author, Professor, Dept. of Business Administration, Seoul Digital University, Seoul, Korea [Postal Address: 424 Gonghang-daero, Gangseo-gu, Seoul, 07654, South Korea] Email: kimyei@sdu.ac.kr
Bon-moo, deceased, who are well known for their well-being. As a result, the Ottogi brand has been sold to consumers through 'Guttaegi'. The positive reputation and the effect of the 'Gubomu Syndrome' is reaffirming the perceptions of LG brand as the image of everyday life of modest and sophistication. However, negative examples include not only the 'Korean Air Peanut Circumstance' incident, 'Hanjin Group's ranting and assault on the family', but also various examples of CEOs of famous companies.

When major social events occur, the reason it can spread to a mass number of people than it could ever have in the past can be contributed to the development of SNS. In other words, information produced by a large portal company was transmitted unilaterally to individuals who needed it in the past. Recently, various sources of information produced in real time through SNS are shared among individuals, through individuals, and to individuals (Kim \& Kim, 2012). As a result, efforts to build a positive corporate image through various activities from the company are suddenly becoming harder and harder to do. A typical example is that of the assault of airline employees by CEO $B$, a representative outdoor company in 2013, causing the effect of social responsibility activities promised to operate about 10 billion 
won in social contribution funds to be bumped up. The cause of this phenomenon is the change of information flow using SNS. Therefore, companies should seriously accept that this change in information flow has a great influence on the agenda setting, which is a common concern of society (Kim \& Kim, 2012).

Thus, this study focuses on the responsibilities of social corporate activities and re-examines the many types of phenomena that occur in companies that have caused some controversies in the past. The concept of socially responsible activities was first introduced in the United States in the 1930s and has come into being in the 1990s and is called "corporate sustainability \& responsibility" (Jung 2006). The reason why this study focuses on corporate social responsibility activities is that these factors affect not only the public but also the various performances of the internal work in the companies. In addition, this study focuses on the importance of the authentic leadership in the CEO's leadership capacity roles as well as the meaningfulness of work perceived by the members of their own work in the company. It is defined that a true leader is a person who shares his authentic mission with the members (George \& Sims, 2007). Moreover, a leader is able to exercise a voluntary influence on the members' missions based on their internalized characters. This is because authentic leaders are highly likely to improve their positive and moral atmospheres, as well as their members', to many stakeholders (Walumbwa et al., 2008). In correlation with this phenomenon, the significance of the members' job is also highly likely to affect the emphasis of positive and moral aspects in terms of interpreting their jobs as well as pursuing and attaining the goal of the job itself (Wong, 1998) In this respect, members should also be able to work on an equal footing with external stakeholders, such as suppliers.

Therefore, this study aims to examine the effect of four economic, legal, ethical and charitable activities on job performance of the members of Carroll (1979). In addition, we confirm that the CEO's authentic leadership and the job merits of each employee are controlled by social responsibility activities and job performance, and the effect of social responsibility activities, authentic leadership, and meaningfulness of work on job performance is specifically confirmed by a 3-way interaction. In addition to the role of legal, economic, and ethical responsibility activities, we examined the influence of the CEO's authentic leadership and employees in the workplace. It is expected that it will be possible to present various implications on what efforts should be made at the enterprise level and the individual level to improve job performance overall for the company.

\section{Theoretical Background}

Bowen (1953) has mentioned the phrase "accepted for the purpose and value of our society, following the actions that are deemed desirable, making decisions and pursuing principles". Not only has its significance been emphasized from the perspective of strategic use of the concept, but it has also been expanded. For example, Buono and Nicholas (1990) argue that companies should contribute not only to the main stakeholders, but also to more stakeholders across society, and contribute to the realization of human values over a broader range of economic values. Other researchers (Brown \& Dacin, 1997; Donaldson \& Preston, 1995; Petkus \& Woodruff, 1992; Wood \& Jones, 1995) have similarly comprehensively enforced the corporate social obligations and a comprehensive obligation to internal and external stakeholders.

The reason why corporate social responsibility activities are considered as an essential and strategic factor rather than an optional one is that the source of the ability to continuously generate wealth is determined by the relationship with all stakeholders (Hahn \& Lee, 2010; Post, Preston, \& Sachs, 2002). Therefore, for sustainable growth and development, companies should not pursue the goal of only maximizing shareholder profit (Friedman, 1980). In other words, not only do all the behaviors that are implemented in the whole process of corporate purpose have to conform to the ethical standards of society (Drucker, 1984), but also actively carry out social responsibility activities in order to improve corporate value over the long term (Donaldson \& Preston, 1995; Hamann, 2003; Hillman \& Keim, 2001; McWilliams \& Siegel, 2001; Wood \& Jones, 1995).

From this point of view, it is somewhat problematic for Korean corporations to focus on charitable responsibility activities mainly in large corporations. This is because charitable actions are likely to be seen only as efforts to improve corporate image through support for relatively isolated groups. In addition, if these efforts are perceived to be unintentional, it is likely to cause adverse effects due to negative corporate images. Therefore, in this study, corporate social responsibility activities were classified into economic, legal, ethical and charitable activities that Carroll (1979) systematically conceptualized. Specifically, economic accountability is the expectation of a company that it will make sound strategies and decisions related to profit creation. Legal accountability means the expectations of the society that the company will comply with relevant laws and regulations related to business activities. Additionally, ethical responsibility means the expectation of the society that the company will do the right and fair action in business activities and charitable responsibility means the 
expectations and the desire for the social contribution and support of companies through good citizenship.

Inherent leadership is the practice of self-awareness and self-discipline by the leader based on his experience, positive competence, and high ethical standards (Park, Seol, \& Lee, 2014). Therefore, the leaders' efforts to recognize the true self based on their reflection of themselves, and to reduce the difference between the ideal self and the present self, leads to the authenticity and development of not only the leader himself but also the members as well (Park et al., 2014; Yang \& Kwon, 2015). This is the most widely used method in the field of aerospace engineering (Avolio \& Gardner, 2005; Gardner, Avolio, Luthans, May, \& Walumbwa, 2005). The reason for focusing on authentic leadership in this study is that authentic leaders may be transactional, participatory, or transformational (Bass \& Steidlmeier, 1999), despite the complexity of leader orientation (Yoon, 2012; Zhu, Avolio, Riggio, \& Sosik, 2011).

Meaningfulness of work was gleaned from the basis of observing Jews who survived forced labor in Nazi prison camps and discovered that the power to maintain life is a meaning of life regardless of physical health (Frankl, 1959; Lim, 2008). Recently, it has also been highlighted by positive psychology. Positive psychology is the process of forming a schema with sense formation to create a sense of security as a key component of how individuals connect one side of life to another (Baumeister \& Vohs, 2005). Therefore, if people find meaning in a variety of situations and events, their motivation for life can be enhanced (Arnold, Turner, Barling, Kelloway, \& McKee, 2007; Britt, Adler, \& Bartone, 2001). From this point of view, meaningfulness of work can be motivated by feeling a positive sense of a worker's job.

The logic that motivation is possible through the job itself has also been presented earlier in the two factor theory of Herzberg (1968). Hackman and Oldham (1976) also found that as job diversity, job identity, and task importance become more significant, job satisfaction increases and job absenteeism and turnover rate decrease.

Park (2012) indicated that the extent to which a member has successfully performed his or her job is one of the indicators of organizational effectiveness. Brown and Peterson (1994) have mentioned that along with this, status (Woo, 2001) has also influencing power in the success of the organization (Ko, Jung, \& Jun, 2013). Therefore, the job performance of corporate members is an important variable that is closely related to the quantitative KPI (Key Performance Indicator) as well as the company's critical CSF (Critical Success Factors) for strengthening competitiveness

\section{Research Methods}

\subsection{Design of the Research}

The purpose of this study is to clarify the role of corporate social responsibility, the CEO's authentic leadership roles and meaningfulness of work. This research has been to investigate and resolve the controversy about gang issues which are emerging as a social problem in recent years. In addition to philanthropic responsibility activities centered on large corporations, it is necessary to determine whether factors play a positive role in this scenario, and to see whether it is because they have a more positive effect.

Additionally, it is generally evaluated that many leadership theories emphasize not only technological aspects for achieving organizational goals (Choi \& Ahn, 2016) but also lack of interest in social care and social responsibilities (Song \& Seomum, 2014). This study will also identify the effects of social responsibility activities on job performance and examine the effects of authentic leadership and job merit on job performance. This was done by K. Lewin's Field Theory (Burnes \& Cooke, 2012), which is a personalized version of Bertz and Judge (2004), which emphasizes the interrelationship of individual and organizational requirements. It also emphasized on the fit between the organization and that it would have a positive impact on not only the group to which it belongs but also to various stakeholders and our society.

Chatman (1989) has made claims that personal organizational suitability is defined as the correspondence between individual value and organization's value, and the relationship between social responsibility activities and CEO's authentic leadership roles. It can be expected that it will be possible not only to achieve optimal job performance but also to enhance organizational performances and play positive roles in society voluntarily. In other words, by confirming the effectiveness of factors such as social responsibility activities, authentic leadership, and meaningfulness of work, it is possible to derive clues that can alleviate many social problems such as various tyrannies of company members in the company's high positions.

Therefore, in this study, we tried to confirm the direct effect of the sub-factors of corporate social responsibility activities on job performance, and confirm whether CEO's authentic leadership and the quality of the job are controlled by social responsibility activities and job performances. In order to apply the personal-organizational fit, we tried to verify the three-way interaction between authentic leadership and job satisfaction between social responsibility 
activities and job performance. Structured research models and hypotheses for this study are presented in Figure 1.

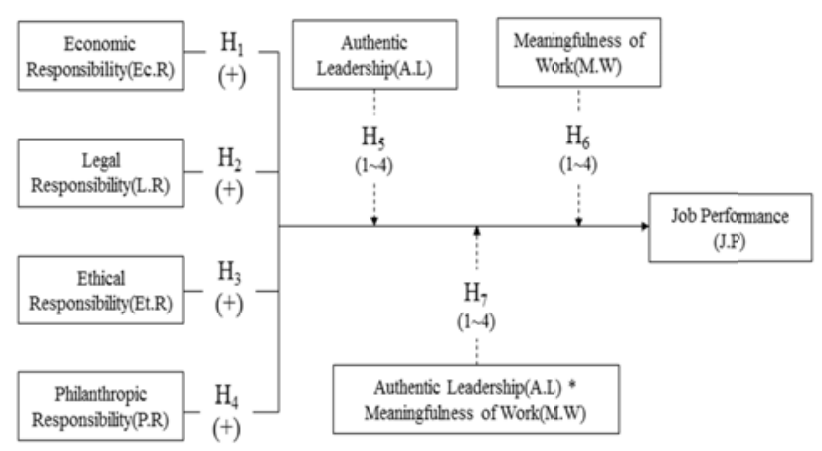

Note: The moderating effect consists of four hypotheses for the sub-factors of social responsibility activities.

Figure 1. Research Model \& Hypotheses

\subsection{Composition of the Questionnaire}

The scale used in this study is as follows. First, based on the researches of Carroll (1991), Maignan and Ralston (2002), and Swaen and Chumpitaz (2008), a total of 7 questions that included "Our company is in compliance with legal responsibilities and standards", "Our company is committed to creating an ethical business climate", "Our company is actively engaged in social service activities" and 6 items of charitable responsibilities were measured on a 5 point Likert scale.

Authentic leadership uses the ALQ (Authentic Leadership Questionnaire) of Walumbwa, Avolio, Gardner, Wernsing, and Peterson (2008) to make a total of 16 questions such as "My CEO honestly acknowledges when he makes a mistake". In terms of the meaningfulness of work, Spreitzer's (1995) Subscale of Meaningfulness of Work was used to measure three items such as "The activities I perform in my job are meaningful to me personally" on a five point Likert scale. Based on a study by Williams and Anderson (1991), job performance was measured using the five-point Likert-type scale, i.e., "I think my work efficiency improved."

\section{Empirical Results}

\subsection{Data Collection and Analysis Methods}

In order to conduct this study, we distributed questionnaires to corporate members working in Seoul and the metropolitan area and used 312 valid questionnaires for analysis. In order to verify the hypothesis, we first checked the reliability and validity, and conducted a correlation analysis to confirm the relationship and direction of the variables. The demographic characteristics of respondents are as follows. In the gender comparison, 188 (60.6\%) were male and $122(39.4 \%)$ were male, and male was the most common (missing, 2) $(24.1 \%)$ in the forties, $73(23.5 \%)$ in the $50 \mathrm{~s}$, and $61(19.6 \%)$ in the $30 \mathrm{~s}$. The education level was $127(40.9 \%)$, followed by $92(29.7 \%)$ college graduates and $91(29.4 \%)$ professional college graduates. The marriage was married with $167(53.7 \%)$ and over half, and 144 (46.3\%) with unmarried.

The analysis method for hypothesis verification is as follows. Direct effect validation was performed by regression analysis after controlling for demographic characteristics that were related to variables. The regulatory effect verification constructs the interaction term between the independent variable and the regulatory variable and performs regression with hierarchical regression. Finally, a 3-way interaction term of the independent variable and the two control variables was constructed and regression was performed.

\subsection{Results of Data Analysis}

\subsubsection{Results of Reliability, Validity and Correlation Analysis}

The results of the confirmatory factor analysis are as follows. As a result of the fact that the standard load of the item "Our company strives to reduce the cost and operation cost" of the subordinate factor of social responsibility activity is less than 0.5 , Construct reliability was $0.859 \sim 0.896$ and Average Variance Extracted (AVE) was $0.504 \sim 0.590$. "In the case of authentic leadership, the standard load of the item" My CEO rejects the pressure against his beliefs "was less than 0.5. As a result of controlling and analyzing this item, the construct reliability was 0.940 and the AVE was 0.514 . On the other hand, the construct reliability of the meaningfulness of work was 0.918 and the AVE was 0.790 . Construct reliability and AVE of the dependent variable were 0.9010 and 0.648 , respectively. Cronbach's a coefficient was 0.874 for economic responsibility, 0.885 for legal responsibility, 0.893 for ethical responsibility, 0.926 for charitable responsibility, 0.930 for authentic leadership, and 0.930 for job responsiveness. For job performance, it was 0.894 .

The results of the correlation analysis between the variables are shown in Table 1. As a result of the analysis, all the variables were statistically significant $(+)$ and expected to be causal. However, the coefficient of correlation between economic responsibility, legal 
responsibility and ethical responsibility was higher than 0.7 . All three parameters were applied and multiple collinearity diagnosis was performed through multiple regression analysis of job performance. As a result of the collinearity test, Durbion-Watson coefficient was 1.969 , Tolerance was 0.345 , Legal liability was 0.291 , Ethical liability was 0.224 , Variance Inflation Factor (VIF) was 2.895, 3.439 and 4.469, respectively, and it was concluded that there was no multicollinearity problem at the standard of 10 or less.

\subsubsection{Hypothesis Verification}

In order to verify each of the hypotheses presented in Figure 2, the variables gender, age, educational attainment, marital status, tenure and job title (duties composed of workers and executives) were observed. Regression analysis was performed, and 3-way interaction regression was used. For regression analysis, each variable was converted to z-score and used for analysis. The results of analysis are presented in Table 2 and Table 5.

Table 1. Results of Correlation Analysis $(n=312)$

\begin{tabular}{|l|c|c|c|c|c|c|c|}
\hline & $\mathbf{1}$ & $\mathbf{2}$ & $\mathbf{3}$ & $\mathbf{4}$ & $\mathbf{5}$ & $\mathbf{6}$ & $\mathbf{7}$ \\
\hline 1. Ec.R. & $(.504)$ & & & & & & \\
\hline 2. L.R. & $.731^{* *}$ & $(.543)$ & & & & & \\
\hline 3. Et.R. & $.801^{* *}$ & $.836^{* * *}$ & $(.538)$ & & & & \\
\hline 4. P.R. & $.663^{* * *}$ & $.580^{* * *}$ & $.719^{* *}$ & $(.590)$ & & & \\
\hline 5. A.L. & $.648^{* * *}$ & $.596^{* * *}$ & $.691^{* *}$ & $.556^{* *}$ & $(.514)$ & & \\
\hline 6. M.W. & $.504^{* * *}$ & $.461^{* * *}$ & $.493^{* *}$ & $.384^{* *}$ & $.458^{* *}$ & $(.790)$ & \\
\hline 7. J.P. & $.408^{* * *}$ & $.479^{* * *}$ & $.476^{* *}$ & $.409^{* *}$ & $.385^{* *}$ & $.643^{* *}$ & $(.648)$ \\
\hline Mean & 3.60 & 3.88 & 3.68 & 3.38 & 3.70 & 4.23 & 3.92 \\
\hline S.D & 0.84 & 0.84 & 0.89 & 1.04 & 0.78 & 0.84 & .081 \\
\hline
\end{tabular}

Note: ** $p<.01$, AVE is marked in ( ). Ec.R.: Economic Responsibility, L.R.: Legal Responsibility, Et.R.: Ethical Responsibility, A.L. :Authentic Leadership, M.W.: Meaningfulness of Work, J.P.: Job Performance

Table 2. Direct effects of economic responsibility and job performance, and moderating effect of authentic leadership and meaningfulness of work.

\begin{tabular}{|c|c|c|c|c|c|c|}
\hline & & \multicolumn{5}{|c|}{ Dependent Variable: Job Performance } \\
\hline & & \multirow{2}{*}{ Step 1} & \multirow{2}{*}{ Step 2} & \multicolumn{2}{|c|}{ Step 3} & \multirow{2}{*}{ Step 4} \\
\hline & & & & (a) & (b) & \\
\hline $\begin{array}{l}\text { Control } \\
\text { Variable }\end{array}$ & $\begin{array}{l}\text { Gender } \\
\text { Age } \\
\text { Education } \\
\text { Marital Status } \\
\text { Year of Con. } \\
\text { Position_dummy }\end{array}$ & $\begin{array}{l}-.081 \\
-.041 \\
.149^{*} \\
-.013 \\
.160^{*} \\
.102\end{array}$ & $\begin{array}{l}-.075 \\
.002 \\
.157^{* *} \\
-.052 \\
.101 \\
.054\end{array}$ & $\begin{array}{l}-.064 \\
.026 \\
.151^{* *} \\
-.052 \\
.061 \\
.051\end{array}$ & $\begin{array}{l}-.043 \\
-.068 \\
.161^{*+} \\
-.065 \\
.092 \\
.045\end{array}$ & $\begin{array}{l}-.031 \\
-.016 \\
.138 \\
-.067 \\
.052 \\
.038\end{array}$ \\
\hline I.V & Ec.R. & & $.390^{* * *+}$ & $.300^{* * *}$ & $.110^{*}$ & .072 \\
\hline \multirow{2}{*}{ M.V } & A.L.(@) & & & $.180^{\star *}$ & & .025 \\
\hline & M.W.(b) & & & & $.598^{* * *}$ & $.571^{* * *}$ \\
\hline \multirow{3}{*}{ I.T } & Ec.R. ${ }^{*}$ A.L.(@) & & & .082 & & .044 \\
\hline & Ec.R*M.W.(b) & & & & .060 & .057 \\
\hline & A.L*M.W & & & & & .107 \\
\hline 3-way I.T & Ec.R*A.L.*M.W. & & & & & $.168^{*}$ \\
\hline \multicolumn{2}{|l|}{$R^{2}$} & .074 & .219 & .242 & .454 & .468 \\
\hline \multicolumn{2}{|l|}{$\Delta \mathrm{R}^{2}$} & & .145 & .023 & .235 & $\begin{array}{l}\text { (a) }(.226) \\
\text { (b) }(.014)\end{array}$ \\
\hline \multicolumn{2}{|l|}{$\mathrm{F}$} & $4.014^{* *}$ & $12.010^{\text {***t }}$ & $10.522^{\text {*** }}$ & $27.441^{\star * * t}$ & $19.803^{\text {**t* }}$ \\
\hline
\end{tabular}

Note: ${ }^{*} p<.05,{ }^{* *} p<.01,{ }^{* * *} p<.001$, I.V: Independent Variable, M.V: Moderating Variable, I.T: Interaction Term, Year of Con.: Years of continuous service. 
Table 2 shows that economic responsibility $(\beta=.390, p$ $<.01)$ positively affects job performance. However, as shown in step 3 and (b), economic responsibility and job performance have no control over authentic leadership and meaningfulness of work. However, 3-way interaction results $(\beta=.168, p<.05)$ on economic responsibility, authentic leadership, and job merit were found to have a statistically significant positive effect. Thus, Hypothesis 1 and Hypothesis 7-1 were adopted, but Hypothesis 5-1 and Hypothesis 6-1 were rejected. Specific results are shown in Figure 2.

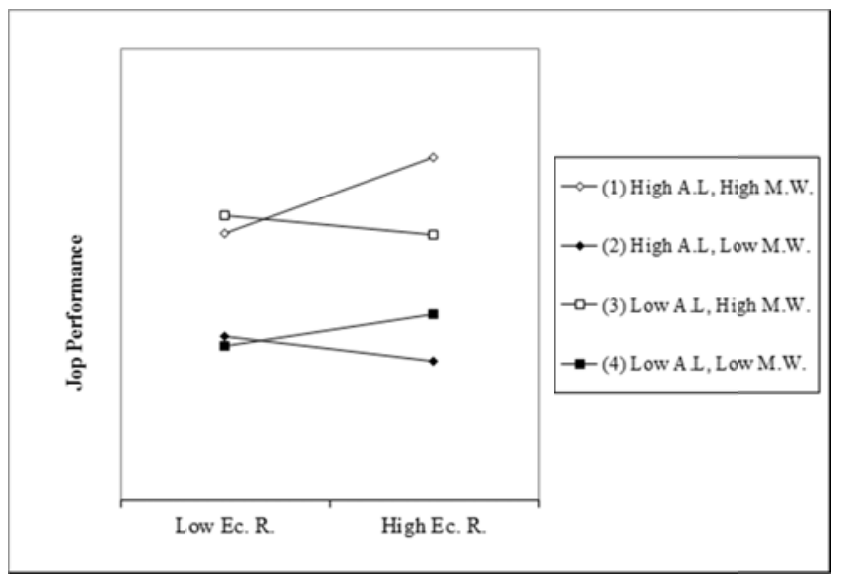

Figure 2. 3-way interaction results of economic responsibility, authentic leadership and meaningfulness of work
This result implies that job performance can be dramatically increased if high level of authentic leadership and high level of job satisfaction are recognized in the context of high economic responsibility activities as compared to low economic responsibility activities of their companies. On the other hand, if a company performs a high level of economic responsibility and the quality of the members' job is high, if the inherent leadership is low, the job performance may be lowered. Even if the CEO manifests authentic leadership in the same responsibility activity situation, it is also noteworthy that job performance is lower when meaningfulness of work is low. Lastly, when CEO's authentic leadership or lack of awareness of job merit is low, it can be interpreted that job performance can be improved by enhancing economic responsibility activities.

Table 3 shows the results of the analysis of the effects of corporate legal responsibility activities on job performance and the role of authentic leadership and meaningfulness of work. As shown in the second stage of Table 3, corporate liability activities $(\beta=.474, p<.01)$ also positively affect job performance. However, as shown in step 3 and 4 , it is confirmed that authentic leadership and meaningfulness of work are not controlled between legal responsibility activities and job performance. On the other hand, 3-way interaction results $(\beta=.218, p<.01)$ on statutory accountability, authentic leadership and job merit were found to have a statistically significant positive effect. Therefore, <Hypothesis $2>$ and $<$ Hypothesis 7-2> were adopted, but $<$ Hypothesis $5-2>$ and $<$ Hypothesis 6-2> were rejected.

Table 3. Direct effects of legal responsibility and job performance, moderating effects of authentic leadership and meaningfulness of work.

\begin{tabular}{|c|c|c|c|c|c|c|}
\hline & & \multicolumn{5}{|c|}{ Dependent Variable: Job Performance } \\
\hline & & \multirow{2}{*}{ Step 1} & \multirow{2}{*}{ Step 2} & \multicolumn{2}{|c|}{ Step 3} & \multirow{2}{*}{ Step 4} \\
\hline & & & & (a) & (b) & \\
\hline & Gender & -.081 & -.080 & -.074 & -.049 & -.037 \\
\hline & Age & -.041 & -.031 & -.015 & -.074 & -.046 \\
\hline Control & Education & $.149^{*}$ & $.153^{* *}$ & $.152^{* *}$ & $.158^{* * *}$ & $.130^{* *}$ \\
\hline Variable & Marital Status & -.013 & -.103 & -.097 & -.096 & -.087 \\
\hline & Year of Con. & $.160^{*}$ & .116 & .088 & .091 & .067 \\
\hline & Position_dummy & .102 & .121 & .113 & .072 & .074 \\
\hline I.V & L.R. & & $.474^{n+m}$ & 428 & $.245^{\mathrm{mm}}$ & $.239^{\prime \prime \prime}$ \\
\hline \multirow{2}{*}{ M.V } & A.L.(@) & & & .110 & & -.072 \\
\hline & M.W.(b) & & & & $.538^{* * *+}$ & $.541^{* *+*}$ \\
\hline \multirow{3}{*}{ I.T } & L.R. *A.L.(@) & & & .069 & & .045 \\
\hline & L.R*M.W.(b) & & & & .050 & .082 \\
\hline & A.L*M.W & & & & & .119 \\
\hline 3-way I.T & L.R*A.L. ${ }^{*}$ M.W. & & & & & $.218^{n+1}$ \\
\hline \multicolumn{2}{|l|}{$\mathrm{R}^{2}$} & .074 & .288 & .299 & .491 & .510 \\
\hline \multicolumn{2}{|l|}{$\Delta \mathrm{R}^{2}$} & & .214 & .011 & .203 & $\begin{array}{l}\text { (a) }(.211) \\
\text { (b) }(.019)\end{array}$ \\
\hline \multicolumn{2}{|l|}{$\mathrm{F}$} & $4.014^{* *}$ & $17.296^{* * *}$ & $14.103^{* * * *}$ & $31.840^{\text {t*t* }}$ & $23.438^{*+1+t}$ \\
\hline
\end{tabular}

Note: ${ }^{*} p<.05,{ }^{* *} p<.01,{ }^{* * *} p<.001$, I.V: Independent Variable, M.V: Moderating Variable, I.T: Interaction Term, Year of Con.: Years of continuous service. 
In Figure 3, it is found that CEO's high degree of authentic leadership and recognition of high job merits increase job performance. In addition to the above-mentioned economic responsibility activities, even if the members' job performance is high, even if they recognize low level of authentic leadership, or if the CEO develops authentic leadership, when the perception of Korea is low, it can enhance job performance by enhancing corporate accountability.

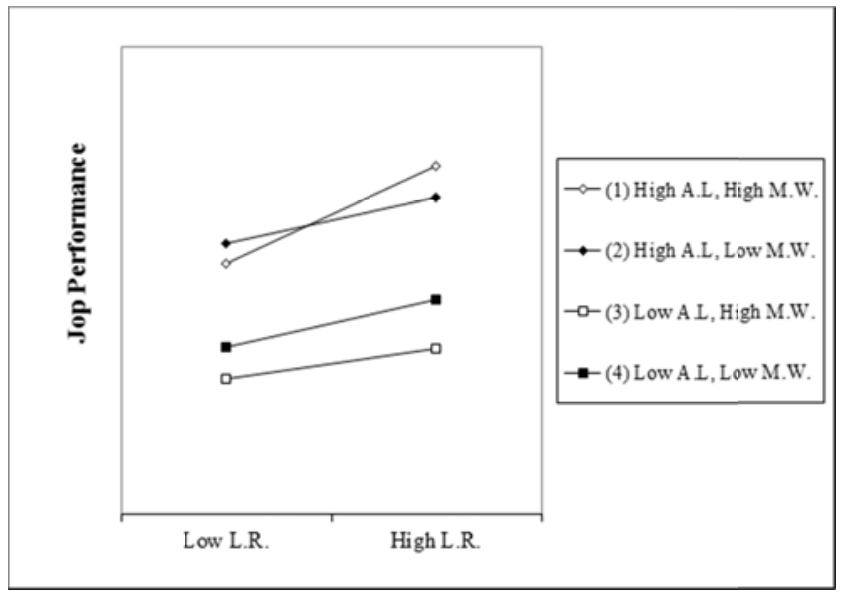

Figure 3. 3-way interaction results of legal responsibility, authentic leadership and meaningfulness of work
The results of this study are summarized as follows. First the effects of ethical responsibility activities on job performance and authentic leadership and meaningfulness of work are shown in Table 4. As shown in the second stage of Table 4, corporate ethical responsibility activities ( $\beta$ $=.464, p<.01$ ) also positively affect job performance. In addition, as shown in step 3 (a) and (b), ethical responsibility activities and job performance are characterized by authentic leadership (interaction term $\beta$ $=.138, p<.01$ ) and job qualities (interaction term $\beta=.122, p$ $<$ ) were found to have modulatory effects. In other words, when the ethical responsibility of the company is high, if the CEO's level of authentic leadership is raised, the job performance will increase. However, in the case of the meaningfulness of work, when the ethical responsibility of the company is high, if the level of the CEO's authentic leadership is increased, the job performance is high. Therefore, it was found that the meaningfulness of work for the members is a more important factor in enhancing job performance than the CEO's authentic leadership.

On the other hand, 3-way interaction results $(\beta=.230, p$ $<.01$ ) on ethical responsibility, authentic leadership and job merit were found to have a statistically significant positive effect. Thus, Hypothesis 3, Hypothesis 5-3, Hypothesis 6-3, and Hypothesis 7-3 were all adopted.

Table 4. Direct effects of ethical responsibility and job performance, and moderating effect of authentic leadership and meaningfulness of work.

\begin{tabular}{|c|c|c|c|c|c|c|}
\hline & & \multicolumn{5}{|c|}{ Dependent Variable: Job Performance } \\
\hline & & \multirow{2}{*}{ Step 1} & \multirow{2}{*}{ Step 2} & \multicolumn{2}{|c|}{ Step 3} & \multirow{2}{*}{ Step 4} \\
\hline & & & & (a) & (b) & \\
\hline $\begin{array}{l}\text { Control } \\
\text { Variable }\end{array}$ & $\begin{array}{l}\text { Gender } \\
\text { Age } \\
\text { Education } \\
\text { Marital Status } \\
\text { Year of Con. } \\
\text { Position_dummy }\end{array}$ & $\begin{array}{l}-.081 \\
-.041 \\
.149^{*} \\
-.013 \\
.160^{*} \\
.102\end{array}$ & $\begin{array}{l}-.043 \\
.002 \\
.162^{* *} \\
-.064 \\
.049 \\
.083\end{array}$ & $\begin{array}{l}-.032 \\
-.002 \\
.153^{\text {*t }} \\
-.044 \\
.024 \\
.086\end{array}$ & $\begin{array}{l}-.036 \\
-.084 \\
.168 \\
-.061 \\
.068 \\
.057\end{array}$ & $\begin{array}{l}-.019 \\
-.038 \\
.134^{* *} \\
-.058 \\
.028 \\
.061\end{array}$ \\
\hline I.V & L.R. & & $.464^{\mathrm{nNx}}$ & $.447^{n+x}$ & $.199^{\mathrm{nxx}}$ & $.223^{\mathrm{kx*}}$ \\
\hline \multirow{2}{*}{ M.V } & A.L.(a) & & & .088 & & -.066 \\
\hline & M.W.(b) & & & & $.586^{* * *}$ & $.537^{* * *}$ \\
\hline \multirow{3}{*}{ I.T } & L.R.*A.L.(@) & & & $.138^{* *}$ & & .096 \\
\hline & L.R*M.W.(b) & & & & $.122^{*}$ & $.200^{* *}$ \\
\hline & A.L*M.W & & & & & .008 \\
\hline 3-way I.T & L.R*A.L. ${ }^{*} M . W$. & & & & & $.230^{n *}$ \\
\hline \multicolumn{2}{|l|}{$\mathrm{R}^{2}$} & .074 & .272 & .292 & .472 & .513 \\
\hline \multicolumn{2}{|l|}{$\Delta \mathrm{R}^{2}$} & & .198 & .02 & .200 & $\begin{array}{l}\text { (a) }(.221) \\
\text { (b) }(.041)\end{array}$ \\
\hline \multicolumn{2}{|l|}{$\mathrm{F}$} & $4.014^{m+n}$ & $15.944^{\mathrm{nxx}}$ & $13.617^{n \times x}$ & $31.353^{\mathrm{nNx}}$ & $23.725^{n \times x}$ \\
\hline
\end{tabular}




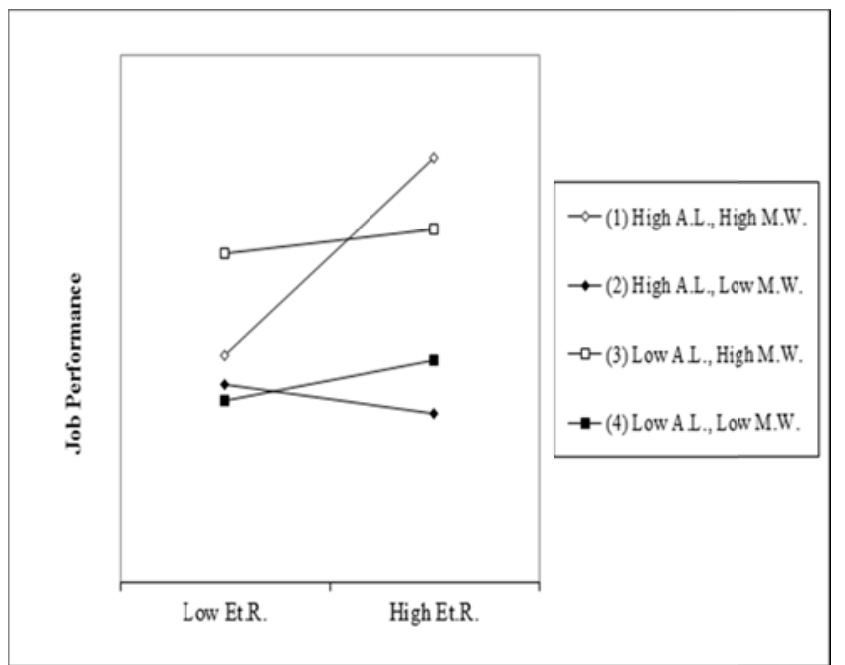

Figure 4. 3-way interaction results of ethical responsibility, authentic leadership and meaningfulness of work

The results of Figure 4 indicate that the higher the level of authentic leadership and the higher level of job satisfaction, the higher the job performance can be. On the other hand, if a company has a high level of ethical responsibility activities and the quality of the members 'job is high, it can be seen that even though the CEO's authentic leadership is low, the job performance becomes a little higher. In addition, when the CEO's authentic leadership is low and employees' meaningfulness of work is low, higher ethical responsibility activities can improve job performance. However, it should be noted that, in the case where the quality of the members' job is low, the performance of the CEO is lowered when the ethical responsibility of the CEO is enhanced. This result means that if the members do not have meaning for their job, they do not care about enhancing the CEO's authentic leadership and ethical responsibility activities.

Finally, Table 5 shows the effects of charitable responsibility activities on job performance and the role of authentic leadership and the meaningfulness of work. As shown in the second stage of Table 5, corporate charitable accountability $(\beta=.393, p<.01)$ also positively affects job performance. In addition, as shown in step 3 (a), authentic leadership (interaction term $\beta=.151, p<.01$ ) shows statistically significant moderating effects between supportive responsibility activities and job performance. In other words, the high level of authentic leadership of the CEO enhances the job performance when the corporate supportive responsibility is high. However, as shown in step 3 (b), job satisfaction (interaction term $\beta=.049, p=.284$ ) showed no adjustment effect between supportive responsibility activities and job performance.

Table 5. Direct effects of support responsibilities and job performance, and moderating effects of authentic leadership and the meaningfulness of work.

\begin{tabular}{|c|c|c|c|c|c|c|}
\hline & & \multicolumn{5}{|c|}{ Dependent Variable: Job Performance } \\
\hline & & \multirow{2}{*}{ Step 1} & \multirow{2}{*}{ Step 2} & \multicolumn{2}{|c|}{ Step 3} & \multirow{2}{*}{ Step 4} \\
\hline & & & & (a) & (b) & \\
\hline $\begin{array}{l}\text { Control } \\
\text { Variable }\end{array}$ & $\begin{array}{l}\text { Gender } \\
\text { Age } \\
\text { Education } \\
\text { Marital Status } \\
\text { Year of Con. } \\
\text { Position_dummy }\end{array}$ & $\begin{array}{l}-.081 \\
-.041 \\
.149^{*} \\
-.013 \\
.160^{*} \\
.102\end{array}$ & $\begin{array}{l}-.089 \\
.002 \\
.157^{*+} \\
-.063 \\
.058 \\
.080\end{array}$ & $\begin{array}{l}-.066 \\
.041 \\
.142 \\
-.070 \\
.006 \\
.070\end{array}$ & $\begin{array}{l}-.046 \\
-.052 \\
.155^{* *} \\
-.081 \\
.055 \\
.050\end{array}$ & $\begin{array}{l}-.030 \\
-.009 \\
.134^{* *} \\
-.085 \\
.022 \\
.049\end{array}$ \\
\hline I.V & L.R. & & $.393^{\mathrm{nn+1}}$ & $.299^{\mathrm{x} \times x}$ & $.190^{\mathrm{n} \times x}$ & $.173^{\mathrm{nx}}$ \\
\hline \multirow{2}{*}{ M.V } & P.L.(a) & & & $.238^{* * *}$ & & .013 \\
\hline & M.W.(b) & & & & $.578^{* * * *}$ & $.542^{* * *}$ \\
\hline \multirow{3}{*}{ I.T } & P.R.*A.L.(@) & & & $.151^{* *}$ & & .091 \\
\hline & P.R*M.W.(b) & & & & .049 & .044 \\
\hline & A.L*M.W & & & & & .008 \\
\hline 3-way I.T & P.R*A.L.*M.W. & & & & & .142 \\
\hline \multicolumn{2}{|l|}{$\mathrm{R}^{2}$} & .074 & .216 & .266 & .475 & .491 \\
\hline \multicolumn{2}{|l|}{$\Delta \mathrm{R}^{2}$} & & .198 & .05 & .259 & $\begin{array}{l}\text { (a) }(.225) \\
\text { (b) }(.016)\end{array}$ \\
\hline \multicolumn{2}{|l|}{$F$} & $4.014^{\mathrm{m*}}$ & $15.944^{\mathrm{nmm}}$ & $11.981^{\mathrm{xN}}$ & $29.848^{\mathrm{n} \times x}$ & $21.761^{\text {"Not }}$ \\
\hline
\end{tabular}


On the other hand, the 3-way interaction results $(\beta=.142$, $\mathrm{p}=.058$ ) on charitable accountability, authentic leadership, and job merit were not statistically significant. This result should be interpreted as the fact that charitable responsibility activities currently carried out do not have an effect on the enhancement of job performance in the case where the workability of members is not secured. Thus, Hypothesis 4 and Hypothesis 5-4 were adopted, but Hypothesis 6-4 and Hypothesis 7-4 were rejected. Although we did not set the hypothesis, we examined whether factors such as corporate social responsibility activities increase job performance, subordinate factors of social responsibility activities, authentic leadership, and job satisfaction, respectively. As a result of the analysis, it was confirmed that only statutory responsibility activities $(\beta=.324, p<.01)$ and charitable responsibility activities $(\beta=.152, p<.05)$ were statistically significant for social responsibility activities. On the other hand, the results of all variables showed that job satisfaction $(\beta=.534, p<.01)$, legal accountability $(\beta=.266$, $p<.01)$, social responsibility activities $(\beta=.156, p<(P<.05)$

\section{Discussion and Managerial Implication}

This study examines the relationship between the subordinate factors of corporate social responsibility activities and job performance as well as the role of CEO's authentic leadership and the meaningfulness of work and its conclusion and implication.

First, it was confirmed that each factors of corporate social responsibility activities increase the job performance of members. Among them, legal responsibility activities were identified as one of the most important factors. In this respect, it is very likely that the illegal acts of CEOs representing a company will inevitably have a negative impact on the performance of its members and affect the organization as a whole. Therefore, at the enterprise level, it is necessary not only to comply with laws and regulations related to business, but also to adhere to the laws and regulations on corruption among stakeholders.

Second, the moderating effects of the CEO's authentic leadership roles and the meaningfulness of work in terms of the corporate social responsibility activities and the job performance demonstrate that authentic leadership is controlled for each factors of ethical responsibility activity, job performance, charitable responsibility activity and job performance. In the case of the meaningfulness of work, it was confirmed that statistically significant adjustments were made between ethical responsibility activities and job performances. This result can enhance the performance of the company when the CEO's authentic leadership is implemented while performing a high level of ethical responsibility activities and philanthropic responsibility activities. Also, when performing a high level of ethical responsibility activities, this can also be an indication that the job performance can be enhanced. This result suggests that the role of the CEO's authentic leadership and the meaningfulness of work of the members and the ways to promote it are needed.

Third, it was confirmed that the results of the 3-way interaction on each sub-factor of corporate social responsibility activities, authentic leadership, and job merit derived somewhat different results. In general, when a company performs a high level of social responsibility activities, it is natural that the performance of the CEO can be enhanced if the executive leadership of the CEO is realized and the quality of the members' job is highly recognized. It is noteworthy, however, that in the case of economic responsibility activities, job performance may be deteriorated if the meaningfulness of work of the member and the perception of the CEO's authentic leadership are in opposition. In other words, if a firm recognizes negative effects of either job meaningfulness or authentic leadership in cost reduction efforts and restructuring efforts to secure competitiveness, it can be expected that a competitive strategy can fail. Therefore, at the corporate level, it is necessary to establish and operate various strategies that enable the CEO to be authentic and give meaning to his or her job. In the case of legal responsibility activities, unlike the previous results, it is an important strategy to improve job performance even when employees' sense of duty and CEO's perception of authentic leadership are in opposition, or when both the meaningfulness of work and authentic leadership are low. Therefore, it can be concluded that the efforts to actively protect the related laws and regulations are very important factors for securing the competitiveness of enterprises.

Ethical accountability, however, presents somewhat different results. Specifically, when the quality of the members 'job is low, the CEO's authentic leadership and ethical responsibility activities are enhanced. This implies that if the members do not have meaning for their job, it is highly likely that the CEO's authentic leadership or the company will take a bad view of enhancing ethical responsibility activities. These results suggest that even if the company develops various social responsibility activities, if the problems of corporations or CEOs are encountered, the authenticity of the company or the CEO may be damaged, which may adversely affect the performance of the members. On the other hand, if the company or the CEO of the company loses the qualities of his or her job due to the controversy of the society, or loses his or her job due to any reason, the performance of the individual is lowered. It is highly likely to be a burden to success. 
As a result of reviewing the results of this study and reviewing previous studies, it is concluded that the ethics, calling and compassion of the company (or CEO) and its members will be a key factor in the company's development through individual performance. The following suggestions were made. First, the interaction with the informal system, such as formal activities which can range from the declaration of education or training or ethics that are carried out to promote the ethics defined as the right and just act of the individual or the organization (Carroll, 1979) or compliance with the ethical rules of voluntary members (Treviño, Butterfield, \& McCabe, 1998), can be settled as an ethical culture. This suggests that if the CEO is perceived by the members as an ethical or unethical role model, as in the theory of social learning (Bandura, 1977), the members will also establish standards for their degree of ethics by learning from them.

Therefore, companies and CEOs should encourage high ethical awareness, so that members can learn through their efforts to fully qualify as role models. Second, in the case of the vocation, the CEO will be the basis of the implementation of authentic leadership, and the members can be an important factor to solidify the merits of the job. It is one of the perceptions that members have about the meaning of work by themselves through their interaction with the organization, and through the process of pursuing meaning and goal within it (Dik \& Duffy, 2009). Therefore, it is important for the company to make active social responsibility activities, the CEO to implement practical actions to implement his / her true leadership, and the members to strengthen their respective vocation awareness activities to confirm the meaningfulness of their work. Development can be achieved together. Finally, compassion should be interpreted in the same context. In other words, the sense of mercy is defined as a propensity to solve others' pain by internalizing it with pain (Yoon, 2012). Therefore, when a company, a CEO, or a member of the team responds as if it is my problem, it is hoped that it will be able to become a competitive company that can contribute to society and the nation by containing meaningfulness and authenticity in its job.

\section{Conclusion and Limitations}

This study examines the relationship between the subordinate factors of corporate social responsibility activities and job performance as well as the role of CEO's authentic leadership and the meaningfulness of work and its conclusion and implication. Although this study has found various implications for solving the problems of the CEOs and company members who are currently facing social issues, there are some limitations that need to be supplemented in future studies.

First, respondents who responded to the questionnaire for this study did not clearly reflect actual social responsibility activities for the company. In other words, there was a lack of confirmation of respondents' awareness of various actual activities of companies. Therefore, in future research, it will be possible to elaborate more sophisticated implications by reflecting the members' perception of the degree of corporate social responsibility activities and confirming their effectiveness.

Second, despite the fact that the influential factors such as the positions of the respondents were controlled, they could not confirm the visual differences according to the positions. In other words, the members of the high-ranking book and the members of the relatively low position will have different degrees of information transfer and evaluation of the company policy may be different. Therefore, in future studies, it is necessary to draw more clear implications by examining these factors. Finally, the limitations of common method biases on the limits and measures of self-report questionnaires will need to be solved through various approaches in future researches.

\section{References}

Arnold, K. A., Turner, N., Barling, J., Kelloway, E. K., \& McKee, M. C. (2007). Transformational leadership and psychological well-being: The mediating role of meaningful work. Journal of Occupational Health Psychology, 12(3), 193-203.

Avolio, B. J., \& Gardner, W. L. (2005). Authentic leadership development: Getting to the root of positive forms of leadership. Leadership Quarterly, 16(3), 315-338.

Bandura, A. (1977) Social Learning Theory. Englewood Cliffs, NJ: Prentice Hall.

Baumeister, R. F., \& Vohs, K. D. (2005). The pursuit of meaningfulness in life. In C.R. Snyder \& S.J. Lopez (Eds.), Handbook of Positive Psychology (pp. 608618). Oxford, UK: Oxford University Press.

Bretz, R. D., \& Judge. T. A. (1994). Person-organization fit and the theory of work adjustment: Implications for satisfaction, tenure, and career success. Journal of Vocational Behavior, 44(1), 32-54.

Britt, T. W., Adler, A. B., \& Bartone, P. T. (2001). Deriving benefits from stressful events: The role of engagement in meaningful work and hardiness. Journal of Occupational Health Psychology, 6, 5363. 
Burnes, B., \& Cooke, B. (2012). Kurt Lewin's Field Theory: A Review and Re-evaluation. International Journal of Management Reviews, 15(4), 408-425.

Carroll, A. B. (1979). A three-dimensional conceptual model of corporate performance. Academy of Management Review, 4(4), 497-505.

Cho, Y. H., Cho, S. Y., \& Hong, G. H. (2017). Effects of Authentic Leadership and Team Empowerment on Team Commitment and Team-Level Organizational Citizenship Behavior: Coaching as a Moderator. Korean Journal of Business Administration, 30(4), 657-688.

Choi, H. G., \& Ahn, S. H. (2016). Influence of nurse managers' authentic leadership on nurses' organizational commitment and job satisfaction: Focused on the mediation effects of empowerment. Journal of Korean Academy of Nursing, 46(1), 100108.

Dahlsrud, A. (2008). How corporate social responsibility is defined: An analysis of 37 definitions. Corporate Social Responsibility and Environmental Management, 15(1), 1-13.

Dik, B. J., \& \& Duffy, R. D. (2009). Calling and Vocation at Work: Definitions and Prospects for Research and Practice. The Counseling Psychologist, 37(3), 424450.

Dobrow, S. R., \& Tosti-Kharas, J. (2011). Calling: The development of a scale measure. Personnel Psychology, 64(4), 1001-1049.

Donaldson, T., \& Preston, L. E. (1995). The stakeholder theory of the corporation: Concepts, evidence, and implications. Academy of Management Review, 20(1), 65-91.

Drucker, P. F. (1984). The new meaning of corporate social responsibility. California Management Review, 26(2), 53-63.

Frankl, V. (1959). Man's Search for Meaning. Boston, MA: Beacon Press.

Fry, L. W. (2003). Toward a theory of spiritual leadership. The Leadership Quarterly, 14(6), 693-727.

Friedman, M. (1980). Free to Choose. New York: Harcourt Brace Jovanovich.

Gardner, W. L., Avolio, B. J., Luthans, F., May, D. R., \& Walumbwa, F. (2005). Can you see the real me? A self-based model of authentic leader and follower development. The Leadership Quarterly, 16(3), 343372.

Gardner, W. L., Fischer, D., \& Hunt, J. G. (2009). Emotional labor and leadership: A threat to authenticity? The Leadership Quarterly, 20(3), 466-482.
Gardner, W. L., \& Schermerhorn Jr, J. R. (2004). Unleashing individual potential: Performance gains through positive organizational behavior and authentic leadership. Organizational Dynamics, 33(3), 270-281.

George, B., \& Sims, P. (2007). True North. Discover your Authentic Leadership. San Francisco, CA: John Wiley \& Sons.

George, B., Sims, P., McLean, A. N., \& Mayer, D. (2007). Discovering your authentic leadership. Harvard Business Review, 85(2), 129-138.

Hackman, J. R., \& Oldham, G. R. (1980). Work Redesign. Reading, MA: Addison-Wesley.

Hall, D. T., \& Chandler, D. E. (2005). Psychological success: When the career is a calling. Journal of Organizational Behavior, 26(2), 155-176.

Hamann, R. (2003). Mining companies' role in sustainable development: The 'why' and 'how' of corporate social responsibility from a business perspective. Development Southern Africa, 20(2), 237-254.

Hahn, J. H., \& Lee, J. K. (2010). Corporate Social Responsibility, Organizational Trust, and Organizational Citizenship Behavior with Cynicism as a Moderator. Korean Corporation Management Review, 32, 25-43.

Herzberg, F. (1968). One more time: How do you motivate employees?. Harvard Business Review, 46, 53-62.

Hillman, A. J., \& Keim, G. D. (2001). Shareholder value, stakeholder management, and social issues: What's the bottom line. Strategic Management Journal, 22, 125-139.

Jung, G. Y. (2006). Report: Current Situation and Future Tasks of Social Responsibility Management in Korea. Seoul: Korea Chamber of Commerce and Industry, BISD.

Kim, J. K., \& Kim, J. S. (2012). The Effect of Relationship Building through SNS on an Individual's Intention to Share Information. Information Policy, 19(2), 57-84.

Ko, B. K., Jung, H. J., \& Jun, J. K. (2013). The Effects of Emotional Labor on Job Satisfaction and Job Performance among Flight Attendants: The Mediating Role of Emotional Exhaustion. Journal of Tourism \& Leisure Research, 25(8), 337-353.

Lm, C. H. (2008). Organizational behavior (4th ed.), Seoul, Korea: B\&M Books.

Maignan, I., \& Ralston, D. A. (2002). Corporate Social Responsibility in Europe and the U.S.: Insights from Businesses' Self-presentations. Journal of International Business Studies, 33(3), 497-514. 
McWilliams, A., \& Siegel, D. (2001). Corporate social responsibility: A theory of the firm perspective. Academy of Management Review, 26(1), 117-127.

Park, R. Y., Selo, H. D., \& Lee, J. H. (2014). The Relationship between Authentic Leadership and Employee Performance: Mediating Effect of Social Identity and Moderating Effect of Perceived Social Exchange Relationship. Korean Journal of Business Administration, 27(11), 2013-2039.

Post, J. E., Preston, L. E., \& Sachs, S. (2002). Redefining the Corporation: Stakeholder Management and Organizational Wealth. Stanford, CA: Stanford University Press.

Singhal, M., \& Chatterjee, L. (2006). A Person-Organization Fit-based Approach for Spirituality at Work Development of a Conceptual Framework. Journal of Human Values, 12(2), 161-178.

Spreitzer, G. M. (1995). Psychological empowerment in the workplace: Construct definition, measurement, and validation. Academy of Management Journal, 38(5), 1442-1465.

Song, B. R., \& Seomun, G. A. (2014). The influential factors related to organizational citizenship behavior of nurses: With focus on authentic leadership and organizational justice. Journal of Korean Academy of Nursing Administration, 20(2), 237-246.

Swaen, V., \& Chumpitaz, R. C. (2008). Impact of Corporate Social Responsibility on Consumer Trust. Recherche et Applications en Marketing (English Edition), 23(4), 7-33.

Treviño, L. K., Butterfield, K. B., \& McCabe, D. L. (1998). The ethical context in organizations: influences on employee attitudes and behaviors. Business Ethics Quarterly, 8(3), 447-476.

Walumbwa, F. O., Avolio, B. J., \& Gardner, W. L., Wernsing, T. S., \& Peterson, S. J. (2008). Authentic leadership: development and validation of a theory-based measure. Journal of Management, 34(1), 89-126.

Willams, L. J., \& Anderson, S. E. (1991). Job satisfaction and organizational commitment as predictors of organizational citizenship and in-role behaviors. Journal of Management, 17(3), 601-617.

Wong, P. T. P. (1998). Implicit theories of meaningful life and the development of the personal meaning profile. In P. T. P. Wong, \& P. S. Fry (Eds.), The Human quest for meaning: $A$ handbook of psychological research and clinical applications (pp.111-140). Mahwah, NJ: Lawrence Erlbaum Associates.

Woo, S. B. (2001). A Study on the relationship among precedence factors, organization citizenship behavior and job performance focus on hotel employees. Journal of Tourism and Leisure Research, 13(1), 175192.

Wood, D. J., \& Jones, R. E. (1995). Stakeholder mismatching: A theoretical problem in empirical research on corporate social performance. The International Journal of Organizational Analysis, 3(3), 229-267.

Yang, H. C., \& Kwon, J. H. (2015). Effects of Authentic Leadership and Leader-Member Exchange on Employee Psychological Ownership and Organizational Commitment. Journal of Distribution Science 13(11), 23-30.

Yoon, J. K. (2012). What is Authenticity? Seoul, Korea: Haneon.

Zhu, W., Avolio, B. J., Riggio, R. E., \& Sosik, J. J. (2011). The effect of authentic transformational leadership on follower and group ethics. Leadership Quarterly, 22(5), 801-817. 